\title{
THE INTERRELATIONSHIP OF CELL GROWTH AND DIVISION IN HAPLOID AND DIPLOID CELLS OF SACCHAROMYCES CEREVISIAE
}

\author{
JULIAN ADAMS
}

Division of Biological Sciences, University of Michigan, Ann Arbor, MI 48109, USA

\begin{abstract}
SUMMARY
The coordination of cell growth and division has been examined in isogenic haploid and dipioid strains of Saccharomyces cerevisiae. The average cell volume of the haploid and diploid cells was unaffected by a range of environmental conditions and generation times. For most environments and generation times the mean cell volume of diploid cells was between 1.52 and 1.83 of the haploid cell volume. Both haploid and diploid cell volumes were reduced drastically when the cells were grown in the chemostat with glucose as the limiting substrate. In this environment diploid cells have the same mean cell volume as haploid cells. Diploid cells are more clongated than haploid cells, and the characteristic shape (eccentricity) of the cells is unaffected by all environmental conditions and generation times tested. Mother cell volume increased during the cell cycle, although the pattern of this increase was affected by the environmental conditions. Under most growth conditions detectable mother cell volume increase occurred only during the budding phase, whereas under conditions of carbon limitation detectable increase only occurred during the unbudded phase. A consequence of this result is that the mean cell volume of haploids at bud initiation is relatively constant in all environments, including carbon limitation. This suggests that there is a critical size for bud initiation for haploids which is constant and independent of environmental conditions. The results for diploids are more complex. Coordination of growth and division in haploid cells can be explained by a simple model initially developed for prokaryotes by Donachie. A modification of this model is proposed to account for the results with diploids.
\end{abstract}

It is now clear that both eukaryotic and prokaryotic cells in balanced growth tend to maintain a constant size at division $[16,23$, $26,28]$. Yet the mechanisms underlying this coordination are poorly understood. The best known studies of growth and division have examined the effect of different environmental conditions on this relationship in bacteria [e.g., 20], and relatively few detailed studies exist for eukaryotes. In Saccharomyces cerevisiae, the added complication of the coordination of growth and division at different ploidy levels is introduced. To date most analyses of this topic in yeast have used cells of unspecified or undetermined genomic constitution. However, any comprehensive theory of growth and division in this organism must incorporate differences in size and growth kinetics exhibited by haploid and diploid cells, and must also consider the effect of generation time and environment on these differences. Previous studies $[1,32]$ have reported a wide variation in the size differences between isogenic haploid and diploid cells grown in different environments.

In this communication the kinetics of growth and division of isogenic cells of 
Table 1. Cell volume $e^{a}$ in different media (together with $95 \%$ confidence intervals)

\begin{tabular}{|c|c|c|c|c|c|}
\hline \multirow[b]{2}{*}{ Medium } & \multicolumn{2}{|l|}{ Haploids } & \multicolumn{2}{|l|}{ Diploids } & \multirow[b]{2}{*}{$\frac{\text { Diploid }}{\text { Haploid }}$ ratio } \\
\hline & $\begin{array}{l}\text { Cell vol. } \\
\left(\mu \mathrm{m}^{3}\right)\end{array}$ & $\begin{array}{l}\text { Generation } \\
\text { time } \\
\text { (hours) }\end{array}$ & $\begin{array}{l}\text { Cell vol. } \\
\left(\mu \mathrm{m}^{3}\right)\end{array}$ & $\begin{array}{l}\text { Generation } \\
\text { time } \\
\text { (hours) }\end{array}$ & \\
\hline Complex & $51: 89 \pm 2.45$ & $1.26 \pm 0.33$ & $95.19 \pm 2.88$ & $1.20 \pm 0.22$ & 1.83 \\
\hline $\begin{array}{l}\text { Minimal medium } \\
\text { Carbon source: } \\
\text { glucose }\end{array}$ & $55.86 \pm 2.77$ & $2.56 \pm 0.17$ & $84.95 \pm 4.02$ & $2.41 \pm 0.09$ & 1.52 \\
\hline $\begin{array}{l}\text { Minimal medium } \\
\text { Carbon source: } \\
\text { sucrose }\end{array}$ & $46.13 \pm 1.50$ & $2.23 \pm 0.10$ & $72.26 \pm 2.20$ & $3.00 \pm 0.14$ & 1.57 \\
\hline $\begin{array}{l}\text { Minimal medium }{ }^{b} \\
\text { Growth-limited on } \\
\text { inorganic phosphate }\end{array}$ & $50.91 \pm 2.50$ & 4.07 & $93.15 \pm 5.98$ & 4.07 & 1.83 \\
\hline $\begin{array}{l}\text { Minimal medium } \\
\text { Growth-limited on } \\
\text { organic phosphate }\end{array}$ & $53.19 \pm 2.82$ & 4.07 & $90.52 \pm 2.95$ & 4.07 & 1.70 \\
\hline $\begin{array}{l}\text { Minimal medium } \\
\text { Growth-limited } \\
\text { on glucose }\end{array}$ & $43.93 \pm 3.20$ & 4.95 & $44.09 \pm 4.44$ & 4.95 & 1.00 \\
\hline
\end{tabular}

$a$ The parent portions of budding cells only were measured.

Cells grown in chemostats.

Saccharomyces cerevisiae are examined in detail with a view to understanding how growth and division are coordinated in this organism.

\section{MATERIALS AND METHODS}

Haploid strains used were XC500A and XC500B, both derived from S288C [1]. Diploid strains used were SCD3-1, SCD3-2, and SCD3-3 all derived from single zygotes isolated by micromanipulation after conjugation between XC500A and XC500B. The two haploid strains are assumed to be isogenic for all loci except the mating type locus [1] and are similarly assumed to be isogenic to the diploid strains.

Cells were grown in batch culture in unlimited growth phase (with all nutrients in excess), or in chemostats with either glucose, inorganic phosphate, or organic phosphate $(\beta$-glycerol phosphate, medium buffered at $\mathrm{pH}$ ) as the factor limiting growth. Details of these procedures and the defined media used have been described previously [1]. Complex medium used was YEPD [7].

Cells were harvested and photographed immediately against a background of a hemocytometer grid for calibration purposes. The photomicrographs were made with a Zeiss standard WL-research microscope using a high power $(40 \times)$ objective. The major and minor axes of each parent cell and bud were measured directly from the photographic negatives. An average of 200 cells were measured for each ploidy level and each environment. Cell volumes and surface areas were then calculated on the assumption that the shape of the cells (parents and buds) approximated a prolate spheroid.

\section{RESULTS}

\section{Cell volumes in different growth media}

The sizes of haploid and diploid cells were measured in a variety of environments ranging from mid-exponential growth in complex medium, where the generation time is approx. $1 \frac{1}{4} \mathrm{~h}$, to growth in chemostats, with glucose the limiting substrate, where the generation time is close to $5 \mathrm{~h}$. Table 1 shows the average volumes of isogenic haploid and diploid budding cells (parent portion only measured) in six different environments.

The most striking aspect of these results is that the volume of the haploid or diploid cells varies little with growth medium or with generation time. For example, the size 
of haploid cells grown in complex medium at a generation time of $1.26 \mathrm{~h}$ is $51.9 \mu \mathrm{m}^{3}$ and the size of the same cells grown in a chemostat in minimal medium, with growth limited by inorganic phosphate concentration, at a generation time of $4.07 \mathrm{~h}$ is 50.9 $\mu \mathrm{m}^{3}$. The principal exception to the constancy in cell volume is seen in the cells grown in chemostats with glucose as the limiting substrate. In this environment, both haploid and diploid cells are considerably smaller than cells grown in other growth media, and the reduction in size is most marked for diploids. Cells grown on sucrose also exhibit a small size reduction, though not as great as that seen under glucose limitation. Sucrose is not taken up by the cell but first must be hydrolysed by invertase, an enzyme which is external to the cell membrane in Saccharomyces [17]. Consequently these cells may also be limited by glucose, though less acutely. McMurrough \& Rose [21] also reported that ammonium limitation reduced cell volume. However, this medium was not used in the present series of experiments.

\section{Relationship between haploid and diploid cell volumes in the different environments}

A consequence of the constancy of cell volume in the different growth media is that the ratio of diploid cell volume to haploid cell volume varies little, with the exception of growth under glucose limitation. Two features of these results are worthy of mention: (i) the ratio of diploid/haploid cell volumes, with one exception, varies between 1.52 and 1.83 and does not approach the value of two, expected from gene dosage-activity considerations $[1,32]$. These results stand in contrast to previously reported observations $[18,24]$ that there is a strict stoichiometric relationship be- tween cell volume and ploidy level. (ii) Under glucose limitation diploid cells have virtually the same size as haploid cells. This result is unexpected and demands that any model attempting to explain the coordination of growth and division in both haploid and diploid cell lines of $S$. cerevisiae must be more complex than previously thought. This topic will be explored in the discussion below.

\section{Cell shape in different environments}

In accordance with geometric convention, the shape of cells approximating prolate spheroids can best be described by their eccentricity, which is defined as the ratio of the distance between the two foci, divided by distance between the two vertices of the elliptic section. Table 2 shows the eccentricities of the haploid and diploid cells in the different environments. The eccentricities of budded cells and budless cells were not significantly different within all strains, in all environments. The data for both cell types were therefore pooled. Diploid cells are more elongated than haploid cells and this is reflected in the higher eccentricity values. These results are consistent with previously reported results [e.g., 24]. However, it is interesting to note that, despite wide variations in cell volumes, haploid and diploid cells still retain their characteristic shape. For example, diploid cells which are grown under glucose limitation still maintain the same eccentricity as diploid cells grown in YEPD, in spite of the fact that there is a two-fold difference in cell volume. A similar conclusion may be drawn from a consideration of the correlations between eccentricity and cell volume. The correlations (see table 2) are, in all but two cases, non-significant, indicating that the eccentricity of a cell in any one environment is not influenced by its size, but must largely 
Table 2. Cell ${ }^{a}$ shape of haploids and diploids

\begin{tabular}{|c|c|c|c|c|}
\hline \multirow[b]{2}{*}{ Medium } & \multicolumn{2}{|l|}{ Haploids } & \multicolumn{2}{|l|}{ Diploids } \\
\hline & Eccentricity $^{b}$ & $\begin{array}{l}\text { Correlation } \\
\text { between cell } \\
\text { volume and } \\
\text { eccentricity }\end{array}$ & Eccentricity $^{b}$ & $\begin{array}{l}\text { Correlation } \\
\text { between cell } \\
\text { volume and } \\
\text { eccentricity }\end{array}$ \\
\hline Complex & $0.479 \pm 0.026$ & $-0.096^{c}$ & $0.671 \pm 0.012$ & $-0.018^{c}$ \\
\hline $\begin{array}{l}\text { Minimal medium } \\
\text { Carbon source: } \\
\text { glucose }\end{array}$ & $0.466 \pm 0.022$ & $0.104^{c}$ & $0.685 \pm 0.015$ & $0.087^{c}$ \\
\hline $\begin{array}{l}\text { Minimal medium } \\
\text { Carbon source: } \\
\text { sucrose }\end{array}$ & $0.494 \pm 0.021$ & $0.011^{c}$ & $0.691 \pm 0.017$ & $-0.045^{c}$ \\
\hline $\begin{array}{l}\text { Minimal medium } \\
\text { Growth-limited on } \\
\text { inorganic phosphate }\end{array}$ & $0.444 \pm 0.024$ & $-0.196^{d}$ & $0.564 \pm 0.019$ & $-0.281^{i}$ \\
\hline $\begin{array}{l}\text { Minimal medium } \\
\text { Growth-limited on } \\
\text { organic phosphate }\end{array}$ & $0.321 \pm 0.034$ & $0.002^{c}$ & $0.487 \pm 0,018$ & $0.064^{c}$ \\
\hline $\begin{array}{l}\text { Minimal medium } \\
\text { Growth-limited } \\
\text { on glucose }\end{array}$ & $0.458 \pm 0.041$ & $0.116^{c}$ & $0.639 \pm 0.035$ & $-0.250^{c}$ \\
\hline
\end{tabular}

a Mother cells and unbudded cells were measured.

$b$ Together with $95 \%$ confidence intervals.

${ }^{c}$ Not significantly different from zero at $\alpha<0.05$.

${ }^{d}$ Significantly different from zero at $\alpha<0.01$.

be determined at the time of initiation by its ploidy.

Cells grown under phosphate limitation show significantly less eccentricity than the corresponding cells in other media. Electron micrographs of cells grown under these conditions [2] show the cell walls to be considerably thicker than under other conditions. Yeast cell walls consist primarily of equal amounts of a glucan and a partly phosphorylated mannan [22]. Environmental conditions can alter the composition of the yeast cell wall [21] and it may be that limitation of phosphate may alter the phosphorylation of the mannan, change the structure of the cell wall and hence the shape of the cell.

\section{Increase of mother cell volume during the cell cycle}

Several studies have shown that the volume of the mother cell increases perceptibly

during the cell cycle $[11,12,13,25]$. These results refute the long-held notion that the volume of the mother cell is constant and does not change through successive cycles of budding [3, 19]. Evidence for the growth of the mother cell during the cell cycle can be gained by using the size of the bud as an indicator of cell cycle position [9]. Measurements of mother cells and buds were therefore taken for both haploid and diploid cells in an attempt to confirm the recent results that mother cell volume does indeed increase during the cell cycle. The slopes of the lines (regression coefficients) obtained from the regression of mother cell volume on bud volume are presented in table 3 for the same six environments employed previously. The results show that when all cells are considered, budding and budless (unbudded cells are considered to have a bud size $=0$ ), the regression coefficients are significantly greater than zero in all cases, 
Table 3. Regression of mother cell volume against bud cell volume (together with $95 \%$ confidence intervals)

\begin{tabular}{llllll}
\hline & Haploids & & & Diploids & \\
\cline { 2 - 3 } \cline { 5 - 6 } $\begin{array}{l}\text { Considering } \\
\text { all cells } \\
\text { (budded and } \\
\text { unbudded) }\end{array}$ & $\begin{array}{l}\text { Considering } \\
\text { only mother } \\
\text { cells with } \\
\text { buds }\end{array}$ & & $\begin{array}{l}\text { Considering } \\
\text { all cells } \\
\text { (budded and } \\
\text { (unbudded) }\end{array}$ & $\begin{array}{l}\text { Considering } \\
\text { only mother } \\
\text { cells with } \\
\text { buds }\end{array}$ \\
\hline $\begin{array}{l}\text { Complex } \\
\text { Minimal medium }\end{array}$ & $0.316 \pm 0.118^{a}$ & $0.419 \pm 0.159^{a}$ & $0.204 \pm 0.084^{a}$ & $0.195 \pm 0.100^{a}$ \\
$\begin{array}{c}\text { Carbon source: } \\
\text { glucose }\end{array}$ & $0.428 \pm 0.131^{a}$ & $0.467 \pm 0.192^{a}$ & $0.394 \pm 0.143^{a}$ & $0.484 \pm 0.189^{a}$ \\
$\begin{array}{c}\text { Minimal medium } \\
\text { Carbon source: } \\
\text { sucrose }\end{array}$ & $0.281 \pm 0.094^{a}$ & $0.333 \pm 0.125^{a}$ & $0.316 \pm 0.041^{a}$ & $0.393 \pm 0.095^{a}$ \\
$\begin{array}{c}\text { Minimal medium } \\
\text { Growth-limited on } \\
\text { inorganic phosphate }\end{array}$ & $0.462 \pm 0.150^{a}$ & $0.461 \pm 0.204^{a}$ & $0.477 \pm 0.192^{a}$ & $0.570 \pm 0.244^{a}$ \\
$\begin{array}{c}\text { Minimal medium } \\
\text { Growth-limited on } \\
\text { organic phosphate }\end{array}$ & $0.366 \pm 0.175^{a}$ & $0.308 \pm 0.223^{b}$ & $0.273 \pm 0.099^{a}$ & $0.233 \pm 0.137^{\circ}$ \\
$\begin{array}{c}\text { Minimal medium } \\
\text { Growth-limited } \\
\text { on glucose }\end{array}$ & $0.674 \pm 0.267^{a}$ & $0.309 \pm 0.376^{c}$ & $0.959 \pm 0.311^{a}$ & $0.583 \pm 0.655^{\circ}$ \\
\hline
\end{tabular}

a Significantly different from zero at $\alpha<0.001$.

- Significantly different from zero at $\alpha<0.01$.

c Not significantly different from zero $x<0.05$.

representing a significant increase in mother cell volume during part or all of the cell cycle. Furthermore, the magnitudes of the regression coefficients for haploids and diploids are not significantly different, indicating that the rate of increase in cell volume during the cell cycle is similar in both haploids and diploids. Such indirect evidence for the increase in mother cell volume during the cell cycle could be criticized on the grounds that significantly positive coefficients could also be produced if larger mother cells tended to produce larger daughter cells. However, Hayashibe et al. [11] have shown that no such correlation exists. Using synchronous and single cell cultures their results show that bud size at abscission is quite uniform and independent of mother cell volume.

The regression analyses shown in table 3 only consider a linear increase in cell volume during the cell cycle. Johnson [12], using similar data obtained from commercial bakers yeast, claimed that the rate of change of mother cell volume against bud size is curvilinear, the size of the mother cell decreasing shortly after bud initiation, to a minimum, and then increasing. Polynomial regressions up to the fourth degree were fitted to the same data used for table 3 in an attempt to substantiate this curvilinearity. In all cases, only the linear term was significant. Thus the data provide no evidence for anything more than a linear increase in cell volume.

The data described here, together with previously reported results, firmly establish the concept of a mother cell volume increase during the cell cycle. However, this observation raises the possibility that this 
Table 4. Observed and expected sizes of budless cells $\left(\mu \mathrm{m}^{3}\right)$ (together with $95 \%$ confidence intervals)

\begin{tabular}{|c|c|c|c|c|}
\hline \multirow[b]{2}{*}{ Medium } & \multicolumn{2}{|l|}{ Haploids } & \multicolumn{2}{|l|}{ Diploids } \\
\hline & $\begin{array}{l}\text { Mother cell } \\
\text { volume (budless } \\
\text { cells only) }\end{array}$ & $\begin{array}{l}\text { Expected }^{a} \\
\text { mother cell } \\
\text { volume (budless } \\
\text { cells only) }\end{array}$ & $\begin{array}{l}\text { Mother cell } \\
\text { volume (budless } \\
\text { cells only) }\end{array}$ & $\begin{array}{l}\text { Expected }^{a} \\
\text { mother cell } \\
\text { volume (budless } \\
\text { cells only) }\end{array}$ \\
\hline Complex & $47.8 \pm 3.4$ & $41.9 \pm 4.4$ & $84.5 \pm 6.5$ & $86.1 \pm 5.4$ \\
\hline $\begin{array}{l}\text { Minimal medium } \\
\text { Carbon source: } \\
\text { glucose }\end{array}$ & $47.6 \pm 2.9$ & $45.8 \pm 4.8$ & $76.1 \pm 5.9$ & $69.2 \pm 7.1$ \\
\hline $\begin{array}{l}\text { Minimal medium } \\
\text { Carbon source: } \\
\text { sucrose }\end{array}$ & $41.9 \pm 2.5$ & $39.4 \pm 2.9$ & $66.3 \pm 4.8$ & $59.1 \pm 3.8$ \\
\hline $\begin{array}{l}\text { Minimal medium } \\
\text { Growth-limited on } \\
\text { inorganic phosphate }\end{array}$ & $41.1 \pm 4.2$ & $41.1 \pm 4.9$ & $82.2 \pm 6.2$ & $76.0 \pm 9.1$ \\
\hline $\begin{array}{l}\text { Minimal medium } \\
\text { Growth-limited on } \\
\text { organic phosphate }\end{array}$ & $45.0 \pm 4.2$ & $47.1 \pm 5.2$ & $79.7 \pm 4.1$ & $82.3 \pm 5.6$ \\
\hline $\begin{array}{l}\text { Minimal medium } \\
\text { Growth-limited } \\
\text { on dextruse }\end{array}$ & $30.9 \pm 3.6$ & $39.5 \pm 6.3$ & $28.9 \pm 3.0$ & $36.9 \pm 9.8$ \\
\hline
\end{tabular}

a Calculated from the regression of bud cell volume against mother cell volume for those cells with buds, and extrapolation to a bud cell volume of zero.

increase may not be evenly distributed throughout the cell cycle but may be coordinated with and/or determined by the passage of certain cell cycle landmarks. The cell size data of both haploids and diploids were therefore analysed to detect any pattern of cell volume increase.

The data gathered in this study allow the analysis of growth during the cell cycle to be divided into two phases, the unbudding phase and the budding phase. Regression analyses were carried out only on haploid and diploid cells in the budding phase to determine if a mother cell volume increase occurred during the budding phase. Results are shown in table 3 for the same six environmental conditions as before. The significantly positive regression coefficients for haploid and diploid cells grown in the first five environmental conditions indicates a significant increase in size during the budding phase. However, neither haploid nor diploid budding cells grown under glucose limitation appear to increase in size during this phase, as shown by the nonsignificant regression coefficients for this environment.

Cell growth during the unbudded phase of the cell cycle can be analysed by comparing the estimated cell volume at bud initiation with the mean volume of unbudded cells. The results are shown in table 4 for the same environments as before. The pattern of results is exactly the reverse of the pattern for the budded phase of the cell cycle. Although cells in the first five environments increase in cell size during the budded phase of the cell cycle, the figures in table 4 show no cell volume increase during the unbudded phase of growth. The 
average unbudded cell volumes and the estimated cell volumes at bud initiation are approximately the same.

Conversely, in glucose limited cultures, the estimated size of cells at bud initiation is much larger than the mean size of unbudded cells. Thus most of the growth for these cells occurs during the unbudded phase of the cell cycle and not during the budding phase as for cells in the other five growth conditions. Hayashibe et al. [11] using $S$. cerevisiae and Vrana et al. [31] using Candida utilis have noted that most of the increase in cell volume occurred in newborn daughter cells with zero bud scars, although some growth did occur in subsequent cycles. The present data do not permit a critical evaluation of this result. However, it should be pointed out that in a culture in balanced growth, $50 \%$ of the cells are newborn daughters with zero bud scar. Generally the proportion of cells of age $x$, where $x$ is the number of bud scars ideally is $(1 / 2)^{x+1}$. Therefore newborn daughter cells would contribute substantially to the figures in tables 3 and 4, and it may be concluded that these data are not in conflict with those of Hayashibe et al. [11] or Vrana et al. [31].

The data show that the pattern of cell volume increase is altered fundamentally by the environmental conditions in which the cells are growing, and that this pattern can be interpreted as being compensatory in nature. In other words, a cell volume increase in the unbudded phase may not lead to a cell volume increase during the budded phase and vice versa. However, more importantly, a consequence of these results is that for haploid cells, the mean cell volume at bud initiation is remarkably constant considering all environments, including glucose limitation. Diploid cells do not exhibit the same constancy; cells in a glucose limited environment are still less than $50 \%$ the volume of the same cells in unlimited growth conditions, even after allowance for a volume increase during the unbudded phase of growth.

The implications of these results for the control of growth and division in $S$. cere. visiae are explored in the Discussion.

\section{DISCUSSION}

Analyses of cell size in prokaryotes have shown a relationship between this parameter and generation time [20, 29]. This relationship is usually described by the empirical equation

$$
\log _{\mathrm{e}}(\text { cell size })=a+b \mu
$$

where $\mu$ is the reproductive rate and $a$ and $b$ are positive constants. Such a relationship would be expected if $(i)$ there is a constant time for DNA replication; (ii) there is a constant time between initiation of a round of DNA replication and cell division, and (iii) the ratio of cell size/number of chromosome origins is a constant. This model, which was first proposed by Donachie [5], suggests that cell growth and division may be regulated by a cellular initiator for DNA replication synthesized at a rate proportional to the overall increase in size. Alternatively cell growth and division may be tied to an inhibitor of DNA synthesis acting as a relaxation oscillator [27]. These two models are formally indistinguishable, though recent studies on the replication of plasmids of $E$. coli support the control of DNA replication by an inhibitor [4]. Experimental support for such an initiator or inhibitor controlling nuclear division in Physarum has been obtained from phase synchronization experiments $[6,15]$.

At first sight the results presented in this paper suggest that there is no similarity between prokaryotes and eukaryotes in the control of cell growth and division. The fun- 
damental difference between the results trom prokaryotes and the results described here is that in $S$. cerevisiae there is no simple dependence of cell volume on growth rate. For haploids at least, the mean cell volume does not vary appreciably over a wide range of growth rates and environments. Nevertheless it is still possible to explain the results presented here for haploid cells of $S$. cerevisiae in terms of the model presented above.

The assumptions of a constant time interval for DNA replication and a constant time between initiation of a round of DNA replication and cell division are probably valid for $S$. cerevisiae. Under normal conditions bud initiation is closely coupled with the initiation of DNA replication [10], and in the absence of any data to the contrary it is assumed that this coupling is maintained under the less normal conditions of glucose limitation.

In addition, von Meyenburg [30] has shown that over a wide variety of cell growth conditions, the time between bud initiation and abscission is relatively constant. These data therefore endorse the validity of the first two of the assumptions for yeast.

The feature of the model which explains the dependence of cell size on growth rate is the assumption that the ratio of cell size/ number of chromosome origins is a constant. In bacteria the number of chromosome origins is a variable since the mass doubling time can be less than the DNA replication cycle time. This accounts for the larger sizes of rapidly dividing bacterial cells. However, in yeast the number of chromosomes/cell line is fixed and the mass doubling time is always greater than the DNA replication cycle time. Therefore, this same assumption. that the ratio of cell sizc/ number of chromosome origins is a con- stant, will result in a constant cell size which is independent of generation time. In particular, the assumption states that cell size at bud initiation will be constant. Presumptive evidence supporting this expectation comes from the cell size data of haploids under glucose limitation. Although mean volume of unbudded cells under glucose limitation is substantially smaller than in other environments, significant cell volume increase occurs before bud initiation so that cell volume at bud initiation is not appreciably different from that in other environments. Hartwell [9] has suggested that a cell must reach a critical size before bud initiation and DNA replication can occur. This suggestion is consistent with the model and the data presented here indicate that the critical size for haploids is the same for all environments. Implicit then in this discussion of the control of cell growth and division is the existence of a cellular oscillator functioning either as an initiator or inhibitor of DNA replication. It is worth noting that evidence has been reported for the existence of oscillators controlling processes other than mitosis in yeast. Ghosh et al. [8] describes evidence for a continuous oscillator controlling glycolytic fluctuations in Saccharomyces carlsbergensis.

Even though the simple model presented above may be adequate to explain cell growth and division in haploid cells, the behavior of diploid cells makes it clear that a more sophisticated model is necessary to explain growth and division at both ploidy levels. The principal complication in the consideration of diploid cells is the extreme cell volume range found in different environments (see tables 1 and 4 ). Whereas haploid cell volume at bud initiation is reasonably uniform in all environments, diploid cell volume at bud initiation does not exhibit such constancy. The data presented 
in table 4 show that diploid cell volume at bud initiation under glucose limitation is only about $50 \%$ of that under unlimited conditions. Thus cell size at the initiation of DNA replication is not a constant as it is for haploid cells. This conclusion is difficult to reconcile with Donachie's model unless a more complex behavior is assumed for the hypothetical DNA inhibitor or initiator. A possible explanation is to assume that the DNA inhibitor or initiator interacts with a number of attachment sites and that the saturation of these sites triggers DNA replication. The number of attachment sites would then be assumed to be constant (and a minimum) for haploids, and the number for diploids would vary under certain environmental conditions, being reduced to that for haploids by starvation for a carbon source. Previous results that diploid cells are reduced to the physiological status of haploid cells in other respects [32], support such a model.

Implicit in the model is the assumption that cell division is ultimately limited by cell growth. The results presented in this paper are consistent with the predictions of the model and thus support the concept that cell division is ultimately limited by cell growth. The same conclusion has been reached by Johnston et al. [14] in an extensive series of experiments involving temperature-sensitive mutations of the mitotic process in yeast. Clearly though a complete understanding of the control and coordination of cell growth and division must await the determination of the molecular basis of this phenomenon.

I thank S. L. Allen, R. B. Helling, B. LaZerte and J. R. Pringle for helpful comments on the manuscript, and J. L. Ristow for technical assistance. The work was supported in part by grants from the USPHS and the Rackham Graduate School of the University of Michigan.

\section{REFERENCES}

1. Adams, J \& Hansche, P E, Genetics 76 (1974) 327.

2. Adams, J \& Jacobs, R. Unpublished data.

3. Baynes-Jones, S \& Adolf, E F, I cell comp physiol 1 (1932) 387.

4. Cabello, F, Timmis, K \& Cohen. S N, Nature 259 (1976) 285.

5. Donachie, W D, Nature 219 (1968) 1077.

6. Fantes, P A, Grant, W D, Pritchard, R H, Sudberry, P E \& Wheals, A E, J theoret biol 50 (1975) 213.

7. Fink, G R, Methods in enzymol 17 A (1970) 59.

8. Ghosh, A K, Chance, B \& Rye, E K, Arch biochem biophys 145 (1971) 319 .

9. Hartwell, L H, Bacteriol rev 38 (1974) 164.

10. Hartwell, L H, Culotti, J, Pringle, I R \& Reid, B J, Science 183 (1974) 46.

11. Hayashibe, $\mathbf{M}$, Sando, N \& Abe, N, J gen appi microbiol 19 (1973) 287.

12. Johnson, B F, Exp cell res 39 (1965) 577.

13. Johnson, B F \& Lu, C, Exp cell res 95 (1975) 154.

14. Johnston, G C, Pringle, J R \& Hartwell, L H, Exp cell res 105 (1977) 79 .

15. Kauffman, S, Bull math biol 36 (1974) 171.

16. Killander, D \& Zetterberg, A, Exp ceil res 38 (1965) 272

17. Lampen, J O, Antonie van Leeuwenhoek 34 (1968) 1.

18. Laskowski, W, Z Naturforsch 156 (1960) 495.

19. Lindegren, C C \& Haddad, S, Genctica 27 (1954) 45.

20. Maaløe, O \& Kjeldgaard, N O, Control of macromolecular synthesis, Benjamin Inc, New York (1966).

21. McMurrough, I \& Rose, A H, Biochem j 105 (1967) 189.

22. Mill, P J, J gen microbiol 44 (1966) 329 .

23. Mitchison, J M \& Creanor, J, Exp cell res 69 (1971) 244.

24. Mortimer, R K, Radiat res 9 (1958) 312.

25. Mortimer, R K \& Johnston, J R, Nature 183 (1959) 1751.

26. Nurse, P, Nature 256 (1975) 547.

27. Pritchard, R H, Barth, P T \& Collins, J, Symp soc gen microbiol 19 (1969) 263.

28. Schaechter, M, Williamson, J P, Hood, J R \& Koch, A L, J gen microbiol 29 (1962) 421.

29. Slater, M \& Schaechter, M, Bacteriol rev 38 (1974) 199.

30. von Meyenburg, H K, Arch Mikrobiol 66 (1969) 289.

31. Vrana, D, Leiblova, J \& Beran, K, Proc third internat symposium on yeasts II (1973) 285.

32. Weiss, R L, Kukora, J L \& Adams, J, Proc natl acad sci US 72 (1975) 794.

Received August 19, 1976

Accepted December 21, 1976 